\title{
RANCANG BANGUN JARINGAN WIRELESS MENGGUNAKAN MIKROTIK CAPTIVE PORTAL DI SMP AL FALAH ASSALAM SIDOARJO
}

\author{
M. Harist Murdani, Surya Priyambudi, Suzana Dewi \\ Universitas Wijaya Putra \\ muhammadharist@uwp.ac.id, surya@uwp.ac.id, suzanadewi@uwp.ac.id
}

\begin{abstract}
Abstrak
Sebagaimana lazimnya sekolah menengah tingkat pertama di Indonesia, hampir sebagian besar sekolah menengah tingkat pertama tidak memiliki tenaga khusus untuk keahlian teknologi informasi. Terutama pada bidang penyediaan jaringan internet berbasis wireless atau nirkabel. Padahal kebijakan pemerintah Indonesia mengarah kepada pemanfaatan teknologi internet untuk menunjang proses belajar mengajar. Salah satu kebijakan itu adalah adanya UNBK (Ujian Nasional Berbasis Komputer) yang secara tidak langsung memaksa sekolah menengah tingkat pertama menyediakan sebuah ruangan lab beserta isinya, yakni set komputer / PC yang terhubung dengan internet. Akan tetapi, ketersediaan koneksi internet kurang maksimal pemanfaatannya. Dikarenakan jaringan nirkabel akses internet yang bisa menjangkau semua ruang kelas. Saat ini, SMP Al Falah Assalam Tropodo telah memiliki beberapa aplikasi/sistem informasi berbasis web yang siap digunakan, antara lain: (1) Aplikasi Rekap Absensi, (2) Aplikasi Perpustakaan, (3) Aplikasi Pembayaran Siswa, (4) Aplikasi Bimbingan Konseling, (5) Aplikasi Portal Guru, (6) Aplikasi PPDB, (7) Aplikasi Surat Keluar Masuk, dan (8) Sistem Informasi Sekolah. Akan tetapi, aplikasi ini belum bisa dimanfaatkan secara maksimal dikarenakan tidak adanya jaringan yang memadai. Sehingga tidak ada guru/siswa/pihak yayasan yang menggunakan aplikasi tersebut. Untuk memaksimalkan penggunaan aplikasi/sistem informasi berbasis web, kami mengusulkan implementasi jaringan lokal sederhana yang mudah untuk dipelihara dan mudah untuk digunakan dengan menggunakan jaringan wireless dan router yang telah kami konfigurasi sebelumnya. Jadi pihak sekolah tinggal menggunakan saja. Jika jangkauan jaringan wireless kurang, tinggal menambahkan alat dan bisa langsung terhubung ke jaringan. Sehingga, dalam kegiatan ini, kami melakukan desain dan implementasi topologi jaringan wireless dengan router Mikrotik RB450 dan TPLINK access point untuk memaksimalkan penggunaan koneksi internet dan sistem informasi yang sudah dimiliki dan mempermudah pihak sekolah untuk menambah sendiri akses jaringan nirkabel dikarenakan dalam kegiatan ini tidak mencakup semua ruangan kelas..
\end{abstract}

Kata Kunci : Mikrotik Captive Portal, Wireless untuk SMP

\section{PENDAHULUAN}

Sebelum adanya kebijakan UNBK (Ujian Nasional Berbasis Komputer) sebagian besar sekolah menengah tingkat pertama maupun tingkat atas di Indonesia belum memiliki koneksi internet dan personal computer yang didedikasikan khusus sebagai alat bantu media pembelajaran bagi siswa. Namun setelah kebijakan itu keluar, hampir semua sekolah yang memiliki kemampuan untuk pengadaan laboratorium komputer beserta isinya dan koneksi internet berusaha untuk menyediakan fasilitas tersebut. Sebab jika tidak ada, maka sekolah tersebut tidak bisa melaksanakan UNBK

Teknologi Informasi dan Komunikasi 
dan harus menumpang di sekolah lain. Hal ini terjadi di tahun 2015/2016.

Akan tetapi, masih banyak sekolah yang belum bisa menyediakan fasilitas tersebut dikarenakan terkendala oleh kurangnya inisiatif, komitmen dan dukungan dari pimpinan sekolah dan yayasan untuk sekolah swasta.

Oleh karena itu, beberapa kepala sekolah mencoba mengelola dana BOS untuk pengadaan fasilitas tersebut. SMP Al Falah Assalam merupakan salah satu Sekolah Menengah Pertama yang telah memiliki infrastruktur TI(Teknologi Informasi) minimal untuk mendukung pelaksanaan UNBK dan try out untuk UNBK.

Perlu diperhatikan juga, bahwasanya tren penggunaan TI dalam pendidikan yang diawali oleh implementasi e-learning dan sistem informasi untuk mengelola sekolah mulai banyak digunakan dan dijadikan objek penelitian oleh beberapa peneliti. Berdasarkan survey yang dilakukan oleh APJII (Asosiasi Penyelenggara Jasa Internet di Indonesia) tahun 2016 (APJII, 2016) menyebutkan bahwa penetrasi internet di Indonesia adalah sebesar 50.4\% yang meliputi seluruh populasi. Sedangkan utilisasi di bidang pendidikan masih sangat rendah, yakni sebesar $7.8 \%$ untuk mahasiswa dan $6.3 \%$ untuk siswa.

Menurut (Cope \& Kalantzis, 2009), Teknologi Informasi memiliki kemampuan untuk menginspirasi kita dalam mengubah cara hidup, cara mengajar, dan cara belajar. Para pelajar konvensional berubah menjadi pelajar berbasis digital dikarenakan banyaknya akses teknologi yang tersedia. Secara umum, proses pembelajaran digital ini disebut sebagai e-learning. Dalam (Rahmah, Santoso, \& ZA, 2018) memberikan kesimpulan bahwa proses pendewasaan penggunaan e-learning harus melalui proses yang bertahap, yakni pembelajaran konvensional, pembelajaran berbasis web, m-learning, dan e-learning yang bertindak sebagai roadmap pengembangan evolusi pembelajaran.

SMP Al Falah Assalam Tropodo Sidoarjo merupakan salah satu SMP Swasta yang cukup maju jika dibandingkan dengan SMP lain di sekitarnya. Mereka memiliki sarana dan prasarana yang cukup memadai untuk mendukung proses belajar mengajar. Namun, untuk mendukung adopsi teknologi informasi memiliki kendala di dalam dana dan terutama tenaga ahli untuk penyediaan arsitektur jaringan dalam satu sekolah. SMP Al Falah Assalam Tropodo telah memiliki beberapa sistem informasi yang mampu mendukung adopsi teknologi informasi yang merupakan hasil kerjasama dengan sebuah perguruan tinggi di Surabaya yang dapat dilihat di situs web dengan alamat http://www.smpalfalahassalam.sch.id/. Berdasarkan situs ini aplikasi yang telah dimiliki dan siap digunakan antara lain: (1) Aplikasi Rekap Absensi, (2) Aplikasi Perpustakaan, (3) Aplikasi Pembayaran Siswa, (4) Aplikasi Bimbingan Konseling, (5) Aplikasi Portal Guru, (6) Aplikasi PPDB, (7) Aplikasi Surat Keluar Masuk, (8) Sistem Informasi Sekolah. Adanya Sistem Informasi ini mampu meningkatkan nilai akreditasi sekolah hingga mencapai A. Namun pada kenyataannya, sistem informasi ini jarang digunakan oleh pihak sekolah dikarenakan sistem informasi menggunakan hosting di luar sekolah sehingga membutuhkan koneksi internet untuk mengaksesnya. Tidak adanya koneksi internet dikarenakan tidak ada jaringan yang tersedia di lingkungan sekolah untuk mengakses aplikasi/sistem informasi tersebut.

Sebagaimana sekolah lain pada umumnya, SMP AL FALAH Assalam mencoba untuk selalu meningkatkan layanan dan kualitas pada siswanya. Sehingga menerima tawaran dari UPN Surabaya untuk melakukan pengabdian masyarakat dan objek penelitian skripsi di lingkungan sekolah. Hasil dari pengabdian masyarakat dan skripsi ini adalah beberapa aplikasi/sistem informasi berbasis web yang hingga saat ini mangkrak di laman web online sekolah tanpa pernah digunakan sama sekali kecuali aplikasi absensi menggunakan sidik jari saja. Minimnya penggunaan ini dikarenakan alasan teknis dan non teknis. Alasan teknis meliputi tidak adanya koneksi/jaringan dan tenaga ahli untuk mengelola di sekolah untuk mengakses aplikasi/sistem informasi. Sedangkan alasan nonteknis cenderung pada kurangnya pelatihan dan pembiasaan dalam penggunaan aplikasi/sistem informasi.

Oleh karena itu, dalam kegiatan ini, kami melakukan implementasi perluasan jaringan wireless yang terhubung dengan koneksi internet yang dilengkapi dengan penggunaan captive portal untuk pengaturan pengguna dan pemerataan

Teknologi Informasi dan Komunikasi 
keterbatasan bandwidth yang tersedia menggunakan router Mikrotik..

Router Mikrotik menyediakan fungsi untuk captive portal yang dapat didefinisikan sebagai teknik autentifikasi dan pengamanan data yang lewat dari jaringan internal (sekolah) ke jaringan eksternal (internet). Selain itu, captive portal dapat memproteksi atau membatasi adanya trafik/koneksi internet sebelum pengguna melakukan login (Yutanto, 2015).

Dalam (Lubis, Raharjo, \& Sutanta, 2014) membandingkan antara implementasi easyhotspot dan mikrotik dalam penerapan captive portal. Berdasarkan hasil kuesioner yang telah disebar, didapatkan ringkasan sebagaimana dijelaskan di Tabel 1. Mikrotik memiliki hasil yang lebih tinggi daripada easyhotspot. Kesimpulan yang dapat diambil adalah berdasarkan parameter yang telah ditentukan, pada parameter pertama, dan ketiga Mikrotik lebih unggul daripada easyhotspot. Sedangkan pada parameter kedua, Easyhotspot sedikit lebih unggul daripada Mikrotik.

Tabel 1. Ringkasan hasil kuesioner pada (Lubis, Raharjo, \& Sutanta, 2014)

\begin{tabular}{|l|c|c|}
\hline Parameter & Mikrotik & Easyhotspot \\
\hline $\begin{array}{l}\text { Kemudahan } \\
\text { Instalasi }\end{array}$ & 21 & 9 \\
\hline $\begin{array}{l}\text { Kemudahan } \\
\text { konfigurasi }\end{array}$ & 12 & 18 \\
\hline $\begin{array}{l}\text { Tampilan / } \\
\text { interface } \\
\text { yang user } \\
\text { friendly }\end{array}$ & 19 & 11 \\
\hline Jumlah & $\mathbf{5 2}$ & $\mathbf{3 9}$ \\
\hline
\end{tabular}

Alternatif lain sebagai pengganti Mikrotik adalah menggunakan FreeRadius dan Chova Chiili pada server gateway captive portal (Haryadi, Somantri, \& Christyono, 2016); (Tenggono, 2011). Namun metode ini membutuhkan perangkat yang lebih banyak dan lebih mahal daripada Mikrotik Captive Portal yang hanya membutuhkan router Mikrotik saja.

Dalam (Rahman, 2016) dijelaskan bahwa jika terdapat dua router atau lebih dalam topologi jaringan wireless dimana pengguna menginginkan hanya mengingat satu username dan password saja yang bisa digunakan pada kedua router, maka dapat menggunakan konsep SSO (Single Sign On). Yang tentu saja dibutuhkan perangkat keras dan perangkat lunak tambahan untuk merealisasikannya. Solusi ini lebih cocok untuk digunakan di sekolah yang memiliki kebutuhan pengguna yang tinggi dan dilengkapi dengan kapasitas bandwidth internet yang memadai. Untuk sekolah dengan kapasitas bandwidth rendah, lebih disarankan tidak menggunakan fitur SSO karena kurang efektif dan efisien,

(Rusdan \& Sabar, 2019) melakukan penelitian penggunaan RADIUS (Remote Access Dial in User Service) pada jaringan captive portal wireless di Universitas Widyatama. Mereka menyimpulkan bahwa tingkat keamanan dan kenyamanan RADIUS ini adalah cukup aman dan user-friendly. Akan tetapi, kembali lagi bahwa walaupun tanpa RADIUS, Mikrotik Captive Portal memiliki tingkat keamanan yang kami rasa cukup jika diimplementasikan di lingkungan Sekolah Menengah. Mengingat ancaman keamanan lebih kecil daripada implementasi di universitas atau industry yang notabene memiliki sumberdaya yang lebih baik.

Dengan adanya jaringan wireless ini, diharapkan utilisasi sistem informasi dan peran Teknologi Informasi dalam menunjang proses kegiatan belajar mengajar dapat meningkat. Sehingga peran Teknologi Informasi dapat semakin jelas dirasakan oleh guru, siswa, dan elemen sekolah lainnya.

Sebagai tindak lanjut dari instalasi jaringan wireless, kami memberikan pelatihan kepada staf yang telah ditunjuk khusus oleh kepala sekolah untuk melakukan administrasi pengguna dalam captive portal. Sehingga pihak SMP Al Falah Assalam Sidoarjo dapat melakukan pengaturan pengguna dan password secara swadaya sesuai dengan kebutuhan.

Sebagai pengembangan untuk tindakan selanjutnya dapat melakukan monitoring pada bandwidth yang tersedia. Apakah tersebar merata untuk semua pengguna atau hanya digunakan oleh salah seorang pengguna saja. Pada (Sumarta, Informatika, Informasi, Atma, \& Makassar, 2015) menggunakan Queue Tree untuk mengalokasikan bandwidth pada masing-masing pengguna sehingga tidak terjadi pelanggaran pada kuota yang telah ditentukan sebelumnya. Sehingga penggunaan bandwidth menjadi lebih terkontrol dan lebih efektif serta efisien.

Teknologi Informasi dan Komunikasi 


\section{METODE}

Metode Penelitian yang digunakan dalam kegiatan ini adalah sebagai berikut:

\section{a. Pengumpulan Data}

Pada tahapan ini, kami melakukan dua macam pengumpulan data, yang pertama adalah data untuk proses instalasi dan pengaturan captive portal sedangkan yang kedua adalah data untuk membuat topologi jaringan wireless bagi SMP Al Falah Assalam Sidoarjo. Data yang kedua ini didapatkan dengan melakukan visitasi dan wawancara dengan kepala sekolah SMP Al Falah Assalam Sidoarjo.

\section{wireless}

b. Analisa data dan desain topologi jaringan

Berdasarkan kedua data yang diperoleh dari tahapan sebelumnya, maka kami membuat desain topologi jaringan wireless untuk SMP Al Falah Assalam sebagai berikut:

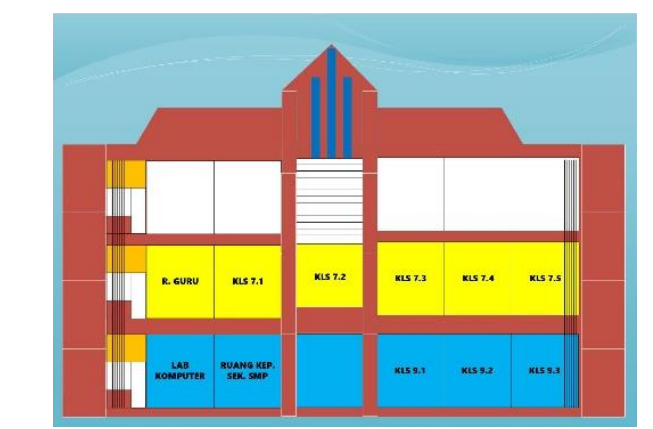

Gambar 1. Skema Gedung sekolah SMP Al Falah Assalam Sidoarjo

Gambar 1 menunjukkan skema gedung sekolah, dimana ruangan yang sudah memiliki koneksi internet terpusat di dalam laboratorium komputer(lantai satu) saja. Unit komputer di dalam lab terhubung menggunakan kabel UTP / LAN (Local Area Network) pada router internet secara langsung.

Gambar 2 menunjukkan desain topologi jaringan wireless yang kami sarankan untuk SMP Al Falah Assalam Sidoarjo. Kami menambahkan 1 router mikrotik RB450 untuk implementasi captive portal dengan jumlah maksimal pengguna adalah 200 pengguna, 2 switch hub TPLINK dan 2 access point TPLINK yang akan diatur di ruang kepala sekolah dan ruang kelas 9.1 yang sering digunakan untuk pelatihan guru-guru. Sedangkan koneksi wireless ke ruang guru dilakukan secara swadaya oleh pihak SMP Al Falah Assalam Sidoarjo.

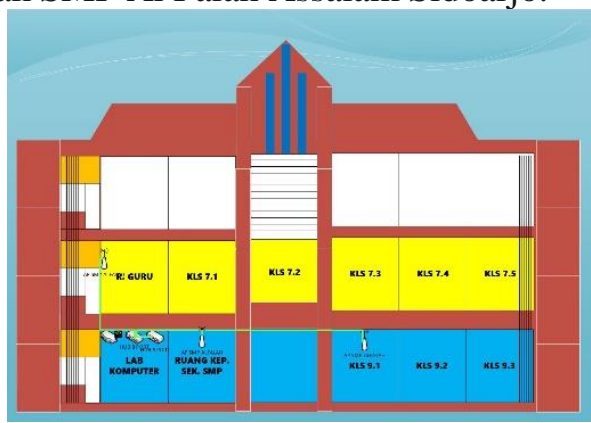

Gambar 2 Desain Topologi Jaringan Wireless SMP Al Falah Assalam

\section{c. Implementasi berdasarkan desain topologi jaringan wireless}

Pada tahapan ini dilakukan koordinasi dengan pihak SMP Al Falah Assalam Sidoarjo terkait pemasangan router, access point, dan penarikan kabel UTP dari laboratorium komputer ke masing-masing access point. Dilanjutkan dengan pengaturan access point dan captive portal dengan user dan grup uji coba yang sudah dipersiapkan sebelumnya.

\section{d. Uji Captive Portal}

Tahapan terakhir adalah pengujian untuk captive portal yang dipasang di dalam router Mikrotik. Kabel UTP dari modem akan dialihkan ke switch hub untuk menyiasati kebutuhan UNBK dan try out agar tidak perlu login terlebih dahulu. Untuk access point yang lain, akan diarahkan ke switch hub yang terhubung dengan router mikrotik. Untuk mewajibkan pengguna agar masuk ke dalam captive portal terlebih dahulu sebelum menggunakan koneksi internet.

Setelah itu dilakukan uji terhadap captive portal dengan mencoba koneksi wireless menggunakan access point yang telah terpasang. Uji coba koneksi jaringan wireless yang telah terpasang dilakukan dengan menggunakan smartphone. Untuk melakukan uji coba bahwa untuk bisa terhubung dengan koneksi internet harus memasukkan username dan password di laman captive portal.

\section{e. Penambahan pengguna baru}

Setelah dilakukan ujicoba captive portal dan telah dianggap berhasil, langkah selanjutnya adalah menambahkan data pengguna baru ke dalam sistem Mikrotik. Data pengguna ini berasal dari data

Teknologi Informasi dan Komunikasi 
para guru dan staf SMP Al Falah Assalam Sidoarjo yang membutuhkan akses koneksi internet untuk menjalankan tugas kesehariannya. Data ini didapatkan dari pihak sekolah dalam format file Microsot Excel. Kami membantu roses penambahan pengguna baru untuk pertama kali, yang nantinya akan dilanjutkan oleh pihak staf sekolah yang telah ditunjuk.

Dikarenakan tidak adanya staf khusus di bidang TIK (Teknologi Informasi dan Komunikasi), kami melaksanakan pelatihan bagi staf terpilih dengan materi tentang pengaturan pengguna dalam captive portal Mikrotik. Yang meliputi, penambahan dan penghapusan pengguna. Pelatihan ini berlangsung secara offline sebanyak dua kali dan online sesuai kebutuhan. Jika staf tersebut tidak bisa mengatasi permasalahan, maka kami bantu untuk menyelesaikan permasalahan tersebut secara remote menggunakan bantuan dari aplikasi Team Viewer.

\section{HASIL DAN PEMBAHASAN}

Gambar 2 merupakan hasil analisa kami mengenai topologi jaringan wireless yang telah disesuaikan dengan besaran dana yang tersedia dan kondisi gedung SMP Al Falah Assalam Surabaya. Desain topologi jaringan di gambar 2 telah disepakati oleh Kepala Sekolah dan biro umum dari SMP Al Falah Assalam Sidoarjo.

Setelah mendapatkan persetujuan, kami segera memasang dan melakukan penarikan kabel dari laboratorium komputer ke titik-titik access point yang direncanakan. Secara keseluruhan, dibutuhkan kabel UTP sepanjang $100 \mathrm{~m}$ untuk menyambungkan antara keduanya.
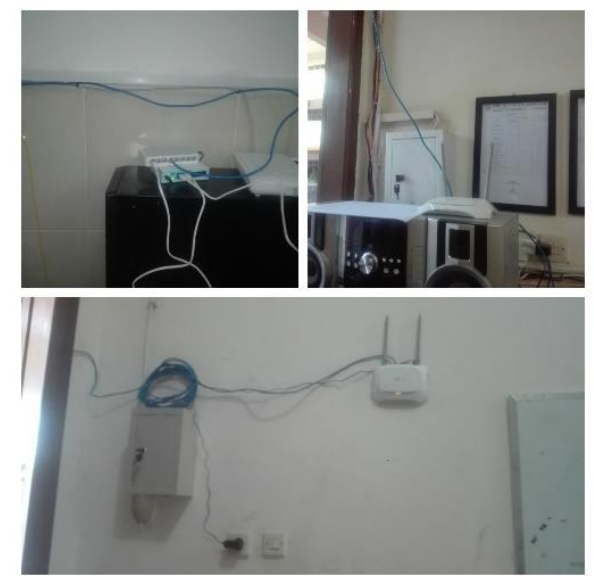

Gambar 3 Hasil Instalasi Router dan Access Point
Gambar 3 menunjukkan instalasi router mikrotik RB450 dan 2 access point TPLINK yang kami pasang. Sesuai rencana awal, 1 access point diletakkan di dalam ruangan kepala sekolah dan satu lagi di dalam ruangan kelas 9.1 dengan pertimbangan sering dilakukan kegiatan pelatihan untuk guru-guru sekolah.

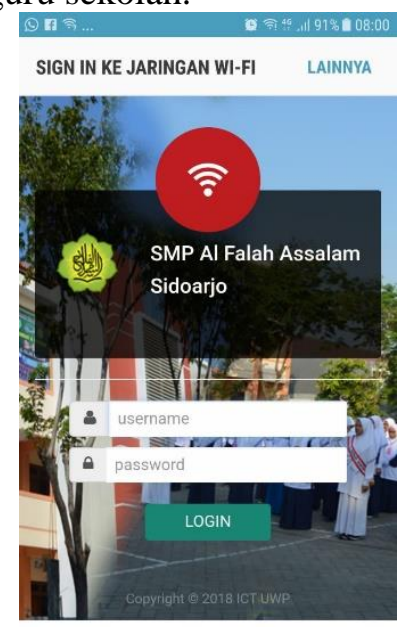
Gambar 4 Hasil Captive Portal Jaringan Wireless SMP
Al Falah Assalam Sidoarjo

Gambar 4 menunjukkan hasil uji captive portal, yang otomatis keluar saat pengguna melakukan koneksi menggunakan perangkat wireless yang telah terpasang. Uji coba dilakukan dengan menghubungkan smartphone ke jaringan wireless yang telah terpasang.

\section{KESIMPULAN}

Beberapa kesimpulan yang dapat diambil dalam kegiatan ini adalah sebagai berikut:

1. Penggunaan captive portal Mikrotik membutuhkan waktu untuk memperkenalkan terhadap pengguna, mengingat sebagian besar pengguna belum memiliki pengetahuan tentang TIK.

2. Penggunaan captive portal Mikrotik mampu membagi bandwidth sesuai dengan hak pengguna masing-masing sehingga tidak terjadi hogging dikarenakan salah satu pengguna menggunakan download manager.

3. Captive Portal telah mampu berfungsi dengan baik dalam membatasi pengguna dalam penggunaan koneksi internet.

Teknologi Informasi dan Komunikasi 
Sedangkan saran yang bisa kami berikan untuk kegiatan yang akan datang adalah sebagai berikut:

1. Sebelum melakukan implementasi Captive Portal, mohon diperhitungkan kapasitas maksimal user dalam router Mikrotik dengan penggunaan yang sebenarnya. Semakin banyak pengguna, maka semakin tinggi pula spesifikasi router yang harus digunakan.

2. Perlu diperhatikan bahwa banyaknya access point berbanding lurus dengan biaya yang harus dikeluarkan dan besaran bandwidth serta panjang kabel UTP yang dibutuhkan.

\section{UCAPAN TERIMAKASIH}

Ucapan terimakasih disampaikan kepada SMP Al Falah Assalam yang telah memberikan kontribusi dalam pelaksanaan kegiatan dengan menjadi mitra.

Ucapan terima kasih disampaikan kepada U niversitas Wijaya Putra yang telah memberikan pendanaan untuk pelaksanaan kegiatan pengabdian internal tahun 2018.

\section{REFERENSI}

APJII. (2016). Infografis Penetrasi \& Perilaku Pengguna Internet Indonesia - Survey 2016. In Polling Indonesia.

Cope, B., \& Kalantzis, M. (2009). Ubiquitous Learning: An Agenda for Educational Transformation. In Proceedings of the 6th International Conference on Networked Learning (pp. 576-582).

Haryadi, M. A., Somantri, M., \& Christyono, Y. (2016). PERANCANGAN MEDIA OTENTIKASI MENGGUNAKAN CAPTIVE PORTAL PADA JARINGAN WIRELESS
LABORATORIUM KOMPUTER TEKNIK ELEKTRO UNIVERSITAS DIPONEGORO Metode. Transient, 5(2), 217.

Lubis, R. F., Raharjo, S., \& Sutanta, E. (2014). Analisa Perbandingan EasyHotspot dan Mikrotik dalam penerapan Hotspot area dengan Sistem AAA. Jarkom, 1(2), 185-189.

Rahmah, A., Santoso, H., \& ZA, H. (2018). Elearning process maturity level: a conceptual framework. Journal of Physics: Conference Series.

Rahman, A. (2016). Implementation of Bandwidth Management Authentication, 1(1), 1-8.

Rusdan, M., \& Sabar, M. (2019). ISSN : 2460-1861 PENGEMBANGAN JARINGAN WIRELESS MENGGUNAKAN USER AUTHENTICATION BERBASIS RADIUS DALAM INDUSTRI 4 . 0 ( Studi Kasus: Universitas Widyatama ) ISSN : 2460-1861. Infotech Journal, 0, 44-52.

Sumarta, S. C., Informatika, P. T., Informasi, F. T., Atma, U., \& Makassar, J. (2015). MANAJEMEN BANDWIDTH DAN PENGGUNA JARINGAN PADA. Journal of Informatics and Information Systems, 85-92.

Tenggono, A. (2011). DESAIN DAN IMPLEMENTASI USER AUTHENTICATION UNTUK FASILITAS HOTSPOT STMIK PALCOMTECH. Jurnal Teknologi Dan Informatika (Teknomatika), 1(3), 184-201.

Yutanto, H. (2015). Manajemen Tata Kelola Captive Portal Hotspot Mikrotik Dan Unifi Controller. E-NARODROID, 1(2). https://doi.org/10.31090/narodroid.v1i2.70 